\title{
Evaluating the impact of psychological entitlement on cyberloafing: the mediating role of perceived organizational justice
}

\author{
Arefeh Rahaei and Reza Salehzadeh \\ Department of Management, Shahid Ashrafi Esfahani University, Isfahan, Iran
}

Impact of psychological entitlement

Received 18 June 2020 Revised 13 September 2020 8 October 2020 Accepted 8 October 2020

\begin{abstract}
Purpose - The purpose of this study is to evaluate the impact of psychological entitlement and perceived organizational justice on cyberloafing.

Design/methodology/approach - In this study, a cross-sectional research design based on a questionnaire method was used to collect the required data from a sample of 226 employees working at selected universities in the city of Isfahan, Iran. To test the research hypotheses, structural equation modeling was used.

Findings - According to the findings, psychological entitlement could have a significant impact on perceived organizational justice and consequently perceived organizational justice could significantly influence cyberloafing. Moreover, psychological entitlement could significantly influence cyberloafing and finally, psychological entitlement could have a significant effect on cyberloafing through perceived organizational justice.
\end{abstract}

Originality/value - This research provides valuable insight for studying the relationship among psychological entitlement, perceived organizational justice and cyberloafing.

Keywords Social media, Perceived organizational justice, Entitlement, Cyberloafing,

Psychological entitlement

Paper type Research paper

\section{Introduction}

Cyberloafing or spending work time using the internet for non-work purposes is an important concern for organizations, as access to the internet has expanded through the use of different electronic devices such as smartphones and tablets (Andel et al., 2019). In this respect, the study by Zoonen $\mathrm{et}$ al. (2014) indicated that $84.1 \%$ of employees had made use of Facebook and Twitter at least once a day. According to Andel et al. (2019), employees spend approximately $2 \mathrm{~h}$ per day engaging in cyberloafing behaviors. There are various viewpoints toward the consequences of cyberloafing (Wu et al., 2020). Previous research suggests that using the internet and social media at work have some positive outcomes such as job performance (Moqbal et al., 2013); better work-life balance (Malik et al., 2010); job satisfaction (Koch et al., 2012) and organizational commitment (Ali-Hassan et al., 2011). On

(C) Arefeh Rahaei and Reza Salehzadeh. Published in Vilakshan - XIMB Journal of Management. Published by Emerald Publishing Limited. This article is published under the Creative Commons Attribution (CC BY 4.0) licence. Anyone may reproduce, distribute, translate and create derivative works of this article (for both commercial and non-commercial purposes), subject to full attribution to the original publication and authors. The full terms of this licence maybe seen at http:// creativecommons.org/licences/by/4.0/legalcode

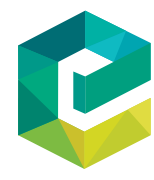

$$
\begin{array}{r}
\text { Vilakshan - XIMB Journal of } \\
\text { Management } \\
\text { Vol. } 17 \text { No. } 1 / 2,2020 \\
\text { pp. } 137-152 \\
\text { Emerald Publishing Limited } \\
\text { e-ISSN: 2633-9439 } \\
\text { p-ISSN: 0973-1954 } \\
\text { DOI 10.1108/XJM-06-2020-0003 }
\end{array}
$$


$\mathrm{XJM}$

$17,1 / 2$

the other hand, many studies have shown that cyberloafing has different negative organizational outcomes (Wu et al., 2020), costing organizations almost $\$ 85 \mathrm{bn}$ per year (Andel et al., 2019). For example, cyberloafing has been found to cause psychological stress (Sonnentag et al., 2018) and negative emotions (Sonnentag, et al., 2017). In addition, cyberloafing reduces organizational productivity (Taylor, 2007) and work engagement (O’Neill et al., 2014). Given the various consequences of using the internet at work; so far, studies have been conducted to identify the factors influencing cyberloafing behaviors. However, it seems that no research has been carried out on the impact of the psychological entitlement and perceived organizational justice on cyberloafing. In this respect, a sense of entitlement means that one person feels that he/she deserves more pay, recognition, positive feedback and other rewards (Lerner and Mikula, 1994). This feeling is accompanied by aggression, greediness, non-ethical behaviors, conflicts and other negative results (Campbell et al., 2004; Harvey and Martinko, 2009). Perceived organizational injustice can also lead to cyberloafing. It is argued that people in organizations are those who perceive the fairness of organizational procedures and transitions by checking and comparing workloads, working time, pay levels, benefits and welfare facilities (Fernandes and Awamleh, 2006). Accordingly, the administrator of an organization may perceive justice in the existing procedures and processes while the subordinates have an unfair perception of them (Lambert and Hogan, 2013). According to the stated contents, the purpose of this study was to evaluate the impact of psychological entitlement and perceived organizational justice on cyberloafing.

\section{Theoretical literature and hypothesis development 2.1 Social media}

Social media are powerful internet-based means of communication used inside and outside the workplace (Holland et al., 2016). There are different perspectives on the advantages and disadvantages of social media. A relationship can be also observed between job satisfaction and willingness to use social media at work (Robertson and Kee, 2016). Furthermore, the use of social media can have a positive impact on job performance (Ali-Hassan et al., 2015). The research results also reported that most of the employees involved in the service sector have agreed that the use of cell phones had improved their productivity while employees working in the production sector believed that the use of cell phones during their work had brought about negative effects (Sarwar and Ghafoor, 2014). Using social media can also have positive effects on access to work-related data, communication with colleagues, as well as knowledge and information sharing. Also, the researchers found that the negative effects of social media tools could outweigh the positive ones if their use at work had not been well managed by human resources management (Munene and Nyaribo, 2013).

\subsection{Psychological entitlement}

Psychological entitlement refers to a stable and pervasive sense that one deserves more and is entitled more than others (Vatankhah and Raoofi, 2018). In this respect, researchers have found that a sense of entitlement is correlated with restlessness at work (Harvey and Harris, 2010), conflicts with supervisors and low levels of job satisfaction (Harvey and Martinko, 2009). In recent years, entitlement has drawn the attention of many researchers (Brown et al., 2009). Although some researchers use entitlement and narcissism instead of each other (Twenge and Campbell, 2009), entitlement can be subsumed for narcissism (Raskin and Terry, 1988). That is, the narcissists have positive and loving views of themselves (DuBrin, 2012). Among the traits of narcissistic individuals; a sense of powerfulness, superiority, 
arrogance, self-acceptance and entitlement can be also highlighted (Foster and Campbell, 2005; Raskin and Terry, 1988).

\subsection{Perceived organizational justice}

Perceived organizational justice is concerned with employees' subjective fairness perceptions in their employment relationship (Hameed et al., 2019). Therefore, the perception of no justice in the workplace can be considered as one of the basic factors affecting the occurrence of aggressive behaviors which can, in turn, heavily damage the creation and maintenance of social capital within an organization (Greenberg and Baron, 2000). As employees in an organization feel that they have been treated unfairly, they can respond emotionally (with less commitment) and behaviorally (increased turnover and decreased consequential behaviors) (Vaezi et al., 2017). It should be noted that, in each social exchange, humans try to compare interests and costs and they would consider it as injustice if it is supposed that costs are greater than interests (Blakely et al., 2005). When employees compare their share with those who slack off, their motivation to make efforts decreases or they take rests to moderate the perceived unfairness (Felps and Mitchell, 2006). Investigations into organizational justice can be based on three dimensions of distributive, procedural and interactional justice (Nadiri and Tanova, 2010). Interacting with each other, these three dimensions of justice can shape the generally perceived justice for individuals at work (Golparvar and Nadi, 2011). Distributive justice refers to perceived justice concerning the allocation of organizational returns and resources (Greenberg and Colquitt, 2005). Procedural justice can also refer to the fairness of methods used for determining occupational consequences (Naami and Shekarshekan, 2005). Procedural justice stands for justice perceived from the ways used to decide about features and results (Nasiri and Beheshti Rad, 2015). Interactional justice also refers to relationships between individuals and organizational behaviors accompanied by respect (Eberlin and Tatum, 2008). This kind of justice has been defined as the quality of interpersonal behaviors especially those by supervisors (Greenberg and Colquitt, 2005).

\subsection{Cyberloafing}

Employees' non-work-related internet at work (such as online shopping, watching online videos (e.g. YouTube), surfing non-work-related online websites and browsing social networking sites (e.g. Facebook and Twitter) is termed as cyberloafing (Koay and Soh, 2018). Currently, we are living in the world of information technology (IT) using computers, tablets, cell phones and the internet. Given that the presence of computers in organizations has led to an increase in productivity, employees have lost their sight of work (Askew, 2012). Despite the benefits of IT, cyberloafing is considered as one of its disadvantages (Cinar and Karcioglu, 2015). So, cyberloafing is a reality within today's organizations in a way that companies have increased access to high-speed internet which is necessary for research and communications (Cinar and Karcioglu, 2015).

\subsection{Relationship between psychological entitlement and perceived organizational justice}

The psychological entitlement means that individuals feel that they deserve more pay, recognition, positive feedback and rewards than others without considering their share at an organization. This feeling can have outcomes such as aggression, greediness, non-ethical behaviors, conflicts and other negative ones (Harvey and Martinko, 2009). It should be noted that individuals in an organization are those who perceive the fairness of organizational procedures and interactions by examining and comparing workload, working time, pay levels, benefits and welfare facilities (Fernandes and Awamleh, 2006). The fact that
Impact of
psychological
entitlement

139 
$\mathrm{XJM}$

$17,1 / 2$

perceived organizational justice stands for equitable distribution of pay and salaries, fair and equal procedures, as well as respect and dignity at work (Vaezi et al., 2017); the consequences of lack of justice in an organization can cause aggressive behaviors, slacking and low commitment. Thus, individuals with a sense of entitlement are likely to perceive the absence of justice in an organization more than others and consequently, the outcomes of non-perception of justice such as reduced performance and increased deviant behaviors can occur more in entitled and narcissist individuals. Accordingly, $H 1$ was developed as follows:

H1. There is a significant relationship between psychological entitlement and perceived organizational justice.

\subsection{Relationship between perceived organizational justice and cyberloafing}

When employees compare their share with those committing cyberloafing, their level of motivation to make efforts is reduced and they seek more rests to moderate the perceived injustice (Felps and Mitchell, 2006). As employees find an organization's behavior toward resource distribution, rewards and interactions between individuals unjust; they also tend to attempt cyberloafing (Lim, 2002). In the study by Zoghbi examining the effect of interactional justice on cyberloafing (Zoghbi, 2006), the results revealed that interactional justice had a negative effect on fear of punishment and such a fear could moderate the relationship between organizational justice and cyberloafing. Thus, the probability of cyberloafing among employees increases if they find their organization's behavior unfair. If such employees also feel that their cyberloafing will be monitored by their organization and they will be severely punished, such behaviors are likely to occur less than ever before. Having a sense of injustice about organizational decision-making and, in general, organizational procedures can have more effects on the distribution of organizational benefits and how interactions occur in an organization in terms of deviant behaviors such as cyberloafing. In general, all three types of organizational justice can negatively affect cyberloafing (Zoghbi and Gonzalez, 2008). Therefore, H2 of this research was developed:

H2. There is a significant relationship between perceived organizational justice and cyberloafing.

\subsection{Relationship between psychological entitlement and cyberloafing}

Psychological entitlement causes restlessness at work (Harvey and Harris, 2010), conflicts with supervisors (Harvey and Martinko, 2009) and low job satisfaction (Harvey and Martinko, 2009). Given that individuals with a sense of entitlement are known as the narcissist with traits such as a sense of arrogance and powerfulness, they consider themselves entitled to have power and demonstrate deviant behaviors such as cyberloafing. Accordingly, $H 3$ addressed in this study was developed as follows:

H3. There is a significant relationship between psychological entitlement and cyberloafing.

\subsection{Relationship between psychological entitlement and cyberloafing through perceived organizational justice}

According to the results, a sense of entitlement was correlated with cyberloafing. Given the fact that perceived organizational justice was correlated with cyberloafing, it was concluded 
that the sense of entitlement could indirectly affect cyberloafing through the mediating role of perceived organizational justice. Thus, $H 4$ of the research was developed as follows:

H4. There is a significant relationship between psychological entitlement and cyberloafing through perceived organizational justice.

The conceptual model of research is presented in Figure 1.

\section{Research methodology}

The statistical population of this study included employees working at selected universities in the city of Isfahan chosen through a simple random sampling method. The data collection instrument was a questionnaire. To calculate the sample size in the studies of structural equations, the relationship of $5 q \leq n \leq 15 q$ is normally used in which $q$ refers to the number of questions in the questionnaire and $n$ stands for the sample size (Safari et al., 2018). Given that there were 29 items in the questionnaire, 250 questionnaires were distributed, of which, 226 questionnaires included the correct data and they were used for data analysis. The overall response rate was estimated at $90.4 \%$. All items were adapted from existing literature and based on validated scales and were measured with a five-point Likert scale ranging from extremely disagree (1) to extremely agree (5).

To measure perceived organizational justice, the questionnaire developed by Niehoff and Moorman (1993) was used. The sense of entitlement and cyberloafing were also measured through the questionnaires by Campbell et al. (2004) and Lim (2002), respectively. The content validity of the questionnaire was verified by several sessions and confirmed by the academia experts in the field of organizational behavior and psychology. The construct validity of the structural model was also measured by factor analysis. The values of factor loadings for the variables were shown in Table 1. In this respect, the results of factor analysis confirmed the validity of all the variables.

The reliability of the questionnaire was calculated using Cronbach's alpha method. As shown in Table 2 the reliability of each factor is above $70 \%$, therefore, the reliability of the questionnaire was confirmed. The SPSS 20 and AMOS 20 software were used for data analysis.

\section{Results}

To test the research hypotheses, structural equation modeling was used. For this purpose, initially, the fitness of the measurement models was separately analyzed and the results of confirmatory factor analysis for the models were confirmed. As observed in Table 3, all three models have a good fit.

After testing the fitness of each measurement model, the structural model of the research was examined. In this respect, the structural model of the study and the fit indices of the model were presented in Figure 2 and Table 4, respectively.

Two indices named critical ratio (CR) and $p$ were used to test the significance of hypotheses. The critical ratio is computed through regression weight divided by the

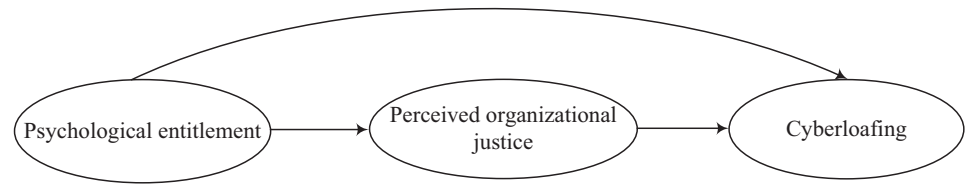

Figure 1. Research conceptual model 


Variables Items

Factor loadings

Organizational justice

1. My working schedule is fair

0.86

2. I think that my pay level is fair

0.54

3. I see the volume of my work quite fair

0.70

4. The rewards I receive from the organization are fair altogether $\quad 0.76$

5. All work-related decisions are made by the manager in an

0.58 unbiased manner

6. Before making a decision, my manager is ensured that the

0.81

views of all employees are heard

7. To make work-related decisions, my manager collects correct and complete information

8. All work-related decisions are equally implemented for employees

9. The employees are allowed to express their opinions about the decisions made

10. When decisions are made about my job, the manager treats me with respect and modesty

11. When decisions are made about my job, the manager shows sensitivity to my personal needs

12. When decisions are made about my job, the manager treats me honestly

13. When decisions are made about my job, the manager provides acceptable explanations

14. The manager explains very clearly about all decisions made about my job

Psychological entitlement

15. Honestly, I feel that I deserve to receive more things than others

16. Excellent events should happen to me

17. If I were on the Titanic, I would deserve to be on the first life boat!

18. I deserve the best

19. I deserve more things in life

20. People like me deserve more rest and comfort

21. I am entitled to all things

Cyberloafing

22. I browse sports websites at work

23. I browse investment websites at work

24. I browse entertainment websites at work

25. I browse news websites at work

26. I browse websites unrelated to my job in the workplace

27. I download information unrelated to my job in the workplace

28. I purchase my personal items online in the workplace

29. I send and receive personal emails at work
0.84

0.66

0.71

0.81

0.72

0.90

0.83

0.81

0.60

0.69

0.79

0.81

0.91

0.65

0.53

0.58

0.41

0.54

0.76

0.67

0.86

0.86

0.69

confirmatory factor analysis

Table 2.

Perceived organizational justice

Psychological entitlement

0.848

Cyberloafing 
standard error. Based on the significance level of 0.05, CR should be greater than 1.96 and under -1.96 (Salehzadeh et al., 2016). Table 5 shows the regression coefficients and values of $\mathrm{CR}$ and $p$ associated to each hypothesis. As can be seen, all hypotheses are verified.

The bootstrap method is used for testing the mediation relationship (Table 6). Considering the fact that zero cannot be among the upper and lower bounds, the mediation hypothesis is confirmed (Safari et al., 2018).

\begin{tabular}{lccccr}
\hline $\begin{array}{l}\text { Fit index } \\
\text { Model }\end{array}$ & CMIN/DF & GFI & IFI & CFI & RMSEA \\
\hline Organizational justice & 3 & 0.9 & 0.93 & 0.93 & 0.09 \\
Psychological entitlement & 1.21 & 0.98 & 0.99 & 0.99 & 0.03 \\
Cyberloafing & 2.94 & 0.95 & 0.96 & 0.96 & 0.09 \\
Goodness of fit & $<3$ & $>0.9$ & $>0.9$ & $>0.9$ & $<0.1$
\end{tabular}

Notes: $\mathrm{CMIN} / \mathrm{DF}=$ normed chi-square; GFI $=$ goodness of fit index; IFI $=$ incremental fit index; $\mathrm{CFI}=$ comparative fit index; RMSEA = root mean squared error of approximation

Table 3.

Fit indices of measurement models

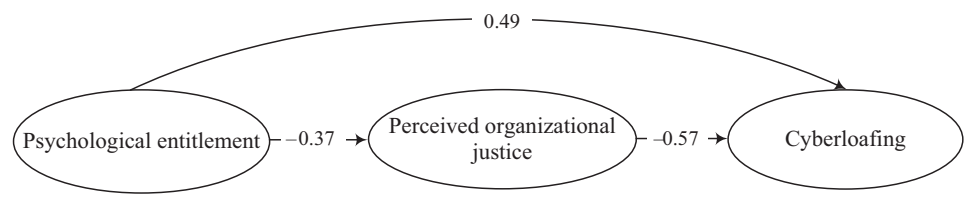

Figure 2.

Structural model results

\begin{tabular}{lccccc}
\hline $\begin{array}{l}\text { Fit index } \\
\text { Model }\end{array} \quad$ CMIN/DF & GFI & IFI & CFI & RMSEA \\
\hline $\begin{array}{l}\text { Structural model } \\
\text { Goodness of fit }\end{array}<3$ & 0.91 & $>0.9$ & 0.95 & 0.95 & 0.06 \\
\hline
\end{tabular}

Table 4. Fit indices of the structural model

\begin{tabular}{llllll}
\hline Path & $\beta$ & CR & P & Results \\
\hline
\end{tabular}

Psychological entitlement has a significant impact on perceived $\begin{array}{lllll}\text { organizational justice } & -0.37 & -4.48 & 0.001 \text { Confirmed }\end{array}$ Perceived organizational justice has a significant impact on cyberloafing $\quad-0.57 \quad-5.76 \quad 0.001$ Confirmed Psychological entitlement has a significant impact on cyberloafing

\begin{tabular}{rrrr}
0.49 & 4.89 & 0.001 & Confirmed \\
\hline
\end{tabular}

Table 5. The results of testing research hypotheses

\begin{tabular}{|c|c|c|c|c|c|}
\hline Path & B & $\begin{array}{l}\text { Lower } \\
\text { bound }\end{array}$ & $\begin{array}{l}\text { Upper } \\
\text { bound }\end{array}$ & Result & \\
\hline $\begin{array}{l}\text { Psychological entitlement has a significant impact on cyberloafing } \\
\text { through perceived organizational justice }\end{array}$ & 0.21 & 0.32 & 1.04 & Confirmed & $\begin{array}{l}\text { The result of testing } \\
\text { mediation hypothesis }\end{array}$ \\
\hline
\end{tabular}


$\mathrm{XJM}$

$17,1 / 2$

\section{Discussion}

This study was an attempt to evaluate the impact of psychological entitlement on cyberloafing through the mediating role of perceived organizational justice. The results of this research confirmed all the hypotheses. Despite the ever-growing importance of the internet and social media and their effects on the quality of individuals' working environment, conducting few investigations in this domain due to the high speed of changes was considered as a research gap.

According to previous literature, there are different behaviors at work (Appelbaum and Roy-Girard, 2007). When behaviors at work are out of the norms defined within an organization, their consequences can become very all-encompassing and then affect the entire levels of an organization such as the processes of decision-making, productivity and financial costs (Coccia, 1998). Researchers have labeled these behaviors with various names including deviant behaviors in the workplace (Robinson and Bennett, 1995). In this respect, deviant behaviors are recognized when "rituals and customs as well as internal policies and regulations of an organization" are violated by an individual or a group (Robinson and Bennett, 1995). One type of deviant behavior is cyberloafing at working time and workplace. Cyberloafing is a new concept and it has not been investigated sufficiently. It is also predicted that the relationship between cyberloafing and other variables at work will be investigated in future studies (Cinar and Karcioglu, 2015).

Moreover, we are living in the age of knowledge and IT which includes instruments such as computers, tablets and cell phones, as well as the internet. In spite of the benefits of IT, employees do their personal everyday tasks at work. Cyberloafing is also considered as one of the disadvantages of IT (Cinar and Karcioglu, 2015) defined as a kind of abuse from the internet access provided by a company because it is used for personal purposes by individuals during working hours. Cyberloafing is similarly known as a voluntary activity as individuals get involved in activities that are enjoyable for them.

One of the main variables of this study was the psychological entitlement. The given sense emerges when an individual expects excessive and optimistic support for one's skills and achievements (Harvey and Harris, 2010). People who consider oneself entitled expect high levels of bonuses without attention to their own share (Harvey et al., 2009). The current generation of employees has a tendency to narcissism and entitlement and they are also endowed with higher self-confidence than previous generations. Moreover, it is argued that the sense of entitlement causes stress; because individuals are exposed to optimistic and unpleasant expectations and feel that they are recognized insufficiently by managers and colleagues (Harvey and Harris, 2010).

The other variable in this study was perceived organizational justice. Particularly, the findings revealed that employees would get involved in cyberloafing as organizations treat employees unfairly in terms of the distribution of rewards, procedures and behaviors (Lim, 2002). It is also acceptable that employees have justifications for cyberloafing within working time as they perceive injustice from managers. For example, they would say that "My boss is not grateful. So, I do whatever every time I like. Cyberloafing is my reaction to the unfair treatment demonstrated by my boss" (Lim, 2002).

\subsection{Managerial implications}

The importance of internet resources toward modern organizations is undeniable; they are integrated into operational processes to improve communication, foster productivity and enhance employee efficiency. However, some employees also take this as an opportunity to slack by cyberloafing when at work (Koay, 2018). Therefore, it is very important for an organization to identify factors influencing cyberloafing 
behaviors. The results of evaluating the impact of psychological entitlement on perceived organizational justice suggested that employees feeling entitled could have lower levels of perceived organizational justice. Moreover, entitled employees have weaker social ties with others. Hence, cyberloafing is a perfect alternate for the purpose of helping them in the virtual world. In this regard, it makes sense to avoid future problems through recruiting individuals without narcissism and a sense of entitlement during the employment process (Harvey et al., 2009). It should be noted that there are several criteria to measure a sense of entitlement which can be used by managers (Campbell et al., 2004). In addition, the results of evaluating the impact of perceived organizational justice on cyberloafing showed that the perception of unfairness within an organization could add to cyberloafing. Thus, to reduce cyberloafing behaviors, organizations need to promote justice in the workplace. In this regard, the volume of work, working schedule and pay level must be fair and all work-related decisions must be made by the managers in an unbiased manner (Lim, 2002). In addition to what was mentioned above, organizations should be able to take steps forwards to reduce cyberloafing; for example, they should monitor the online activities of their employees if needed and also express their own expectations of employees within the policies of the organization (Lim, 2002). Furthermore, organizations can educate employees about the dangers of online threats, online surfing and cyberloafing; and support attitudes that promote a positive work environment (Koay and Soh, 2018). Overall, managers should directly target variables that serve as the impetus for cyberloafing behaviors.

\subsection{Limitations and directions for further research}

With regard to the importance of the internet and its common use, the impact of psychological entitlement and perceived organizational justice was measured and evaluated simultaneously. It was also suggested to measure the impacts of other factors such as leadership styles, occupational attitudes and job performance on cyberloafing (Harvey et al., 2009). In addition, future research can use a qualitative research method to identify unknown factors that can potentially influence cyberloafing behaviors. Furthermore, it should be noted that cyberloafing can be practiced via internet access within an organization or through cell phones, laptops and tablets. Therefore, the severity of the effect of different methods on cyberloafing needs to be measured. Probable consequences of cyberloafing need to be explored in the future, such as hacking into computer systems and abusing data in the workplace which can be related to online behaviors. Besides, it is estimated that the number of employees who consider themselves entitled is on the rise in organizations. Thus, it can be an interesting question for future research (Campbell $e$ t al., 2010). The results of this study were obtained in the context of universities in the city of Isfahan; thus, it is possible to reach different findings in other organizations, cities and countries (due to cultural differences). Some employees in the statistical population had been also affected by some situational factors (such as lack of time); so their levels of participation in terms of appropriate response rate for the questionnaire were low. Given the time constraints, some demographic and psychological characteristics were not included in this study. As mentioned by Andel et al. (2019), cyberloafing is often considered a counterproductive type of withdrawal behavior. However, recent research suggests that cyberloafing may have some unexpected positive workplace outcomes. Therefore, future research can examine the positive consequences of cyberloafing. 
$\mathrm{XJM}$

$17,1 / 2$

\section{References}

Ali-Hassan, H., Nevo, D. and Wade, M. (2015), "Linking dimensions of social media use to job performance: the role of social capital", The Journal of Strategic Information Systems, Vol. 24 No. 2, pp. 65-89.

Ali-Hassan, H., Nev, D., Kim, H. and Perelgut, S. (2011), "Organizational social computing and employee job performance: the knowledge access route. System sciences”, 44th International Conference, HI, pp. 1-10.

Andel, S., Kessler, S., Pindek, S., Kleinman, G. and Spector, P. (2019), "Is cyberloafing more complex than we originally thought? Cyberloafing as a coping response to workplace aggression exposure", Computers in Human Behavior, Vol. 101, pp. 124-130.

Appelbaum, S.H. and Roy-Girard, D. (2007), "Toxins in the workplace: affect on organizations and employees", Corporate Governance: The International Journal of Business in Society, Vol. 7 No. 1, pp. 17-28.

Askew, K.L. (2012), "The relationship between cyberloafing and task performance and an examination of the theory of planned behavior as a model of cyberloafing", University of South Florida, Department of Psychology, Graduate Theses.

Blakely, G.L., Andrews, M.C. and Moorman, R.H. (2005), "The moderating effects of equity sensitivity on the relationship between organizational justice and organizational citizenship behaviors", Journal of Business and Psychology, Vol. 20 No. 2, pp. 259-273.

Brown, R.P., Budzek, K. and Tamborski, M. (2009), “On the meaning and measure of narcissism”, Personality and Social Psychology Bulletin, Vol. 35 No. 7, pp. 951-964.

Campbell, W.K., Bonacci, A.M., Shelton, J., Exline, J.J. and Bushman, B.J. (2004), "Psychological entitlement: interpersonal consequences and validation of a self-report measure", Journal of Personality Assessment, Vol. 83 No. 1, pp. 29-45.

Campbell, W.K., Bonacci, A.M., Shelton, J., Exline, J. and Brad, J.B. (2010), "Psychological entitlement: interpersonal consequences and validation of a self-report measure", Journal of Personality Assessment, Vol. 83 No. 1, pp. 29-45.

Cinar, O. and Karcioglu, F. (2015), "The relationship between cyber loafing and organizational citizenship behavior: a survey study in erzurum/Turkey", Social and Behavioral Sciences, Vol. 207, pp. $444-453$.

DuBrin, A.J. (2012), Narcissism in the Workplace: Research, Opinion and Practice, Edward Elgar Publishing, Northampton, MA.

Eberlin, R. and Tatum, C.B. (2008), "Making justice decisions: organizational justice, decision making, and leadership", Management Decision, Vol. 46 No. 2, pp. 310-329.

Felps, W. and Mitchell, T. (2006), "How, when, and why bad apples spoil the barrel: negative group members and dysfunctional groups", Research in Organizational Behavior, Vol. 27, pp. 181-230.

Fernandes, C. and Awamleh, R. (2006), "Impact of organizational justice in an expatriate work environment”, Management Research News, Vol. 29 No. 11, pp. 701-712.

Foster, J.D. and Campbell, W.K. (2005), "Narcissism and resistance to doubts about romantic partners", Journal of Research in Personality, Vol. 39 No. 5, pp. 550-557.

Golparvar, M. and Nadi, M.A. (2011), "The mediating role of organizational loyalty in the relationship between work ethics and deviant behaviors at work", Journal of Ethics in Science and Technology, Vol. 6 No. 1.

Greenberg, J. and Baron, R.A. (2000), “Behavior in organization”, Rentichall, Vol. 8, pp. 182-183.

Greenberg, J. and Colquitt, J.A. (2005), Handbook of Organizational Justice, Lawrence Erlbaum Associates, Mahwah, NJ.

Hameed, Z., Khan, I.U., Sheikh, Z., Islam, T., Rasheed, M.I. and Naeem, R.M. (2019), "Organizational justice and knowledge sharing behavior: the role of psychological ownership and perceived organizational support", Personnel Review, Vol. 48 No. 3, pp. 748-773. 
Harvey, P. and Harris, K.J. (2010), "Frustration-based outcomes of entitlement and the influence of supervisor communication”, Human Relations, Vol. 63 No. 11, pp. 1639-1660.

Harvey, P. and Martinko, M.J. (2009), "An empirical examination of the role of attributions in psychological entitlement and its outcomes", Journal of Organizational Behavior, Vol. 30 No. 4, pp. 459-476.

Harvey, M., Darren, T., Joyce, T. and Heames, A.D. (2009), "Bullying in the 21st century global organization: an ethical perspective", Journal of Business Ethics, Vol. 85 No. 1, pp. 27-40.

Holland, P., Cooper, B. and Hecker, R. (2016), "Use of social media at work: a new form of employee voice", The International Journal of Human Resource Management, Vol. 27 No. 21, pp. 2621-2634.

Koay, K.Y. (2018), "Workplace ostracism and cyberloafing: a moderated-mediation model", Internet Research, Vol. 28 No. 4, pp. 1122-1141.

Koay, K.Y. and Soh, P.C.H. (2018), "Should cyberloafing be allowed in the workplace?", Human Resource Management International Digest, Vol. 26 No. 7, pp. 4-6.

Koch, H., Gonzalez, E. and Leidner, D. (2012), "Bridging the work/social divide: the emotional response to organizational social networking sites", European Journal of Information Systems, Vol. 21 No. 6, pp. 699-717.

Lambert, E.G. and Hogan, N.L. (2013), "The association of distributive and procedural justice with organizational citizenship behavior", The Prison Journal, Vol. 93 No. 3, pp. 3313-3334.

Lerner, M.J. and Mikula, G. (1994), Entitlement and the Affectional Bond: Justice in Close Relationships, Plenum, New York, NY.

Lim, V. (2002), "The IT way of loafing on the job: cyberloafing, neutralizing and organizational justice", Journal of Organizational Behavior, Vol. 23 No. 5, pp. 675-694.

Malik, M., Saleem, F. and Ahmad, M. (2010), "Work-life balance and job satisfaction among doctors in Pakistan", South African Journal of Management, Vol. 17, p. 112.

Munene, A.G. and Nyaribo, Y.M. (2013), "Effect of social media participation in the workplace on employee productivity", International Journal of Advances in Management and Economics, Vol. 2 No. 2, pp. 141-150.

Nadiri, H. and Tanova, C. (2010), "An investigation of the role of justice in turnover intentions, job satisfaction, and organizational citizenship behavior in hospitality industry", International Journal of Hospitality Management, Vol. 29 No. 1, pp. 33-41.

Nasiri, F. and Beheshti Rad, R. (2015), "Examining the role of glass roofs on reducing perceived organizational justice", Social Studies on Psychology of Women, Vol. 4, pp. 149-172.

O’Neill, T.A., Hambley, L.A. and Bercovich, A. (2014), "Prediction of cyberslacking when employees are working away from the office", Computers in Human Behavior, Vol. 34, pp. 291-298.

Raskin, R. and Terry, H. (1988), "A principal-components analysis of the narcissistic personality inventory and further evidence of its construct validity", Journal of Personality and Social Psychology, Vol. 54 No. 5, pp. 890-902.

Robertson, B.W. and Kee, K.F. (2016), "Social media at work: the roles of job satisfaction, employment status, and Facebook use with co-workers", Computers in Human Behavior, Vol. 70, pp. 191-196.

Robinson, S.L. and Bennett, R.J. (1995), "A typology of deviant workplace behaviors: a multidimentional scaling study”, Academy of Management Journal, Vol. 38, pp. 555-572.

Safari, A., Salehzadeh, R. and Ghaziasgar, E. (2018), "Exploring the antecedents and consequences of organizational democracy", The TQM Journal, Vol. 30 No. 1, pp. 74-96.

Safari, A., Salehzadeh, R., Panahi, R. and Abolghasemian, S. (2018), "Multiple pathways linking environmental knowledge and awareness to employees' green behavior", Corporate Governance: The International Journal of Business in Society, Vol. 18 No. 1, pp. 81-103. 
$\mathrm{XJM}$

$17,1 / 2$

Salehzadeh, R., Khazaei Pool, J. and Soleimani, S. (2016), "Brand personality, brand equity and revisit intention: an empirical study of a tourist destination in Iran", Tourism Review, Vol. 71 No. 3, pp. 205-218.

Sarwar, R. and Ghafoor, A. (2014), "Mobile phones usage and employees' performance: a perspective from Pakistan", International Journal of Academic Research in Accounting, Finance and Management Sciences, Vol. 4 No. 4, pp. 153-165.

Sonnentag, S., Venz, L. and Casper, A. (2017), "Advances in recovery research: what have we learned? What should be done next?", Journal of Occupational Health Psychology, Vol. 22 No. 3, pp. 365-380.

Sonnentag, S., Reinecke, L., Mata, J. and Vorderer, P. (2018), "Feeling interrupted - being responsive: how online messages relate to affect at work", Journal of Organizational Behavior, Vol. 39 No. 3, pp. 369-438.

Taylor, A. (2007), Gambling at Work Costs Employers £300M a Year, In: Financial Times.

Twenge, J.M. and Campbell, W.K. (2009), The Narcissism Epidemic: Living in the Age of Entitlement, Free Press, New York, NY.

Vaezi, R., Hosseinpour, D. and Ranjbar Kaboutarkhani, M. (2017), "The effect of organizational justice on deviant behaviors based on the mediating role of perceived organizational justice", Organizational Behavior Studies, Vol. 5 No. 3, pp. 85-112.

Vatankhah, S. and Raoofi, A. (2018), "Psychological entitlement, egoistic deprivation and deviant behavior among cabin crews: an attribution theory perspective", Tourism Review, Vol. 73 No. 3 , pp. 314-330.

Wu, J., Mei, W., Liu, L. and Ugrin, J.C. (2020), “The bright and dark sides of social cyberloafing: effects on employee mental health in China", Journal of Business Research, Vol. 112, pp. 56-64.

Zoghbi, P. (2006), "Fear in organizations: does intimidation by formal punishment mediate the relationship between interactional justice and workplace internet deviance?", Journal of Managerial Psychology, Vol. 21.

Zoghbi, P. and Gonzalez, S.M. (2008), "The role of anomia on the relationship between organizational justice perceptions and organizational citizenship online behaviors", Journal of Information, Communication and Ethics in Society, Vol. 7 No. 1.

Zoonen, W., Verhoeven, J.W.M. and Elving, W.J.L. (2014), "Understanding work-related social media use: an extension of theory of planned behavior", International Journal of Management, Economics and Social Science, Vol. 3, pp. 164-183.

\section{Further reading}

Aggarwal, P. and O'Brien, C.L. (2008), "Social loafing on group projects structural antecedents and effect on student satisfaction”, Journal of Marketing Education, Vol. 30 No. 3, pp. 255-264.

Amirkhani, T. and Pourezat, A. (2007), "A reflection on the possibility of developing social capital in the light of organizational justice in public organizations", Public Management Journal, No. 1.

Andersson, L.M. and Pearson, C.M. (1999), "Tit for tat? The spiraling effect of incivility in the workplace", The Academy of Management Review, Vol. 24 No. 3, pp. 452-471.

Arshadi, N. and Hashemi, I. (2009), "Relationship between perceived organizational justice and organizational citizenship behavior motivations and organizational citizenship behavior in an industrial organization", Journal of Psychological Achievements (Educational Sciences and Psychology), Vol. 4 No. 2, pp. 219-236.

Bacal, R. (2000), Toxic Organizations - Welcome to the fire of an Unhealthy Workplace, McGraw-Hill, New York, NY.

Ball, G.A., Trevino, L.K. and Sims, H.P. Jr, (1994), "Just and unjust punishment: influences on subordinate performance and citizenship", Academy of Management Journal, Vol. 37 No. 2, pp. 299-318. 
Barlaw, J., Bean, L.A. and Hott, D.D. (2003), “Employee ‘spy' software: should you use it?”, Journal of Corporate Accounting and Finance, Vol. 14 No. 4, pp. 7-12.

Bartlett, J.E., Bartlett, M.E. and Reio, T.G. (2008), "Workplace incivility: worker and organizational antecedents and outcomes", Human Resource Development International Research Conference in the Americas.

Bella, L. and Burke Ronald, J. (2006), "Uncovering the relationship between workaholism and workplace destructive and constructive deviance: an exploratory study", International Journal of Human Resource Management.

Bennett, R.J. and Robinson, S.L. (2000), "Development of a measure of workplace deviance", Journal of Applied Psychology, Vol. 85 No. 3, pp. 349-360.

Brown, T.J. and Sumner, K.E. (2006), "Perceptions and punishments of workplace aggression: the role of aggression content, context, and perceiver variables", Journal of Applied Social Psychology, Vol. 36 No. 10, pp. 2509-2531.

Buhler, P. (2003), "Managing in the new millennium", Supervision, Vol. 64 No. 4, p. 20.

Campbell, W.K. and Foster, J.D. (2007), "The narcissistic self: background, an extended agency model, and ongoing controversies", Frontiers in Social Psychology: The Self, pp. 115-138.

Charoensukmongkol, P. (2014), "Effects of support and job demands on social media use and work outcomes", Computers in Human Behavior, Vol. 36, pp. 340-349.

Chittagisan, A. and Mortazavi, S. (2011), "Factors affecting the phenomenon of social loafing", Strategic Management Thought, No. 1, pp. 161-180.

Chow, W.S. and Chan, L. (2008), "Social network, social trust and shared goals in organizational knowledge sharing", Information and Management, Vol. 45 No. 7, pp. 458-465.

Coccia, C. (1998), "Avoiding a toxic organization”, Nursing Management, Vol. 29 No. 5, pp. 32-34.

Corry, N., Merritt, R.D., Mrug, S. and Pamp, B. (2008), "The factor structure of the narcissistic personality inventory", Journal of Personality Assessment, Vol. 90 No. 6, pp. 593-600.

Cortina, L.M., Magley, V.J., Williams, J.H. and Langout, R.D. (2001), "Incivility in the workplace: incidence and impact", Journal of Occupational Health Psychology, Vol. 6 No. 1, pp. $64-80$.

Cullen, M.J. and Sackett, P.R. (2003), "Personality and counterproductive behavior workplace behavior", in Barrick M. and Ryan A.M. (Eds), Personality and Work, Jossey-Bass-Pfeiffer, New York, NY.

De Hoogh, A.H.B., Den Hartog, D.N. and Nevicka, B. (2013), "Gender differences in the perceived effectiveness of narcissistic leaders", Applied Psychology, Vol. 64 No. 3.

Edmondson, A. (2003), "Speaking up in the operating room: how team leaders promote learning in interdisciplinary action teams", Journal of Management Studies, Vol. 40 No. 6, pp. 1419-1452.

Ferris, D.L., Spence, J.R., Brown, D.J. and Heller, D. (2012), "Interpersonal injustice and workplace deviance: the role of esteem threat", Journal of Management, Vol. 38 No. 6, pp. 1788-1811.

Finkelstein, S. (2005), "When bad things happen to good companies: strategy failure and flawed executives”, Journal of Business Strategy, Vol. 26 No. 2, pp. 19-28.

Ghalavandi, H., Alizadeh, S. and Alizadeh, M. (2016), "Relationship between commitment and perceived organizational justice", Journal of Psychological Education, Vol. 4 No. 4, pp. 111-124.

Golparvar, M. and Ashja, A. (2008), "Relationship between fair organizational beliefs and group cohesion, group respect, participation in decision-making, role conflicts, organizational communication, and job satisfaction", Journal of Human Sciences of Imam Hossein University (AS), Vol. 70 No. 6, pp. 27-58.

Golparvar, M., Javadian, Z., Vaseghi, Z., Masahebi, M. and Ismaeelian, Z. (2015), "Interactional role of perceived organizational justice dimensions on retaliatory behaviors", Scientific-Research Journal of Cognitive Science, Vol. 3 No. 1. 
$\mathrm{XJM}$

$17,1 / 2$

Grijalva, E., Newman, D.A., Tay, L., Harms, M.B. and Harms, P.D. (2015), “Gender differences in narcissism: a meta-analytic review, harms publications”, APA Journal, Vol. 141 No. 2, pp. 261-310.

Hosseini, S.A.R., Sajjadian, Z. and Mohammadi, A. (2017), "Explaining the relationship between organizational values, job stress, and organizational deviant behaviors", the Fifth International Conference of Accounting and Management and the Second Conference of Open Entrepreneurship and Innovation, Hamayshgaran Mehr Eshragh, Tehran.

Huma, Z., Hussain, S., Thurasamy, R. and Malik, M.I. (2017), "Determinants of cyberloafing: a comparative study of a public and private sector organization”, Internet Research, Vol. 27 No. 1, pp. 97-117.

Huseman, R.C., Hatfield, J.D. and Miles, E.W. (1985), "Test for individual perceptions of job equity: some preliminary findings”, Perceptual and Motor Skills, Vol. 61 No. 3_suppl, pp. 1055-1064.

Huseman, R.C., Hatfield, J.D. and Miles, E.W. (1987), "A new perspective on equity theory: the equity sensitivity construct”, Academy of Management Review, Vol. 12 No. 2, pp. 222-234.

Ibrahimi Baloot Bazeh, A. (2011), "Examining the impact of perceived organizational policies and organizational support on deviant behaviors among employees", Master's Thesis, Tarbiat Modarres University.

Javeed, Q.S., Jadhav, S.E. and Dhonde, S. (2012), "Effect of age and gender on social loafing of state level cricket players", Review of Research, No. 1, pp. 1-4.

Jelinek, R. and Ahearn, M. (2006), "The ABC's of ACB: unveiling a clear and present danger in the sales force", Industrial Marketing Management, Vol. 35 No. 4, pp. 457 -467.

Keenan, A. and Newton, T.J. (1985), "Stressful events, stressors, and psychological strains in young professional engineers", Journal of Organizational Behavior, Vol. 6 No. 2, pp. 151-156.

Khaksar, S., Golparvar, M. and Nouri, A. (2007), "The mediating role of perceived organizational justice in the relationship between chronic self-concept of employees and their satisfaction with outcomes, supervisors, and managers", Knowledge and Research in Applied Psychology, Vol. 9 No. 34, pp. 1-26.

Kivimaki, M., Elovainio, M. and Vahtera, J. (2000), "Workplace bullying and sickness absence in hospital staff”, Occupational and Environmental Medicine, Vol. 57 No. 10, pp. 656-660.

Laird, M.D., Harvey, P. and Lancaster, J. (2015), “Accountability, entitlement, tenure, and satisfaction in generation Y”, Journal of Managerial Psychology, Vol. 30 No. 1, pp. 87-100.

Lee, D. (2000), "An analysis of workplace bullying in the UK”, Personnel Review, Vol. 29 No. 5, pp. 593-610.

Lewis, S.E. (2006), "Recognition of workplace bullying: a qualitative study of women targets in the public sector", Journal of Community and Applied Social Psychology, Vol. 16 No. 2, pp. 119-135.

Lewis, S.E. and Orford, J. (2005), "Women's experiences of workplace bullying: changes in social relationships", Journal of Community and Applied Social Psychology, Vol. 15 No. 1, pp. $29-47$.

Mahdad, A. and Iran, M.Z. (2011), "Comparing organizational citizenship behavior and counterproductive behaviors among employees of automotive factories in Iran and Malaysia", New Findings in Psychology, Vol. 12 No. 4, pp. 79-93.

Martin, R. and Hine, D. (2005), "Development and validation of the uncivil workplace behavior questionnaire”, Journal of Occupational Health Psychology, Vol. 10 No. 4, pp. 477-490.

Mayer, D.M., Thau, S., Workman, K.M., Van, D.M. and De Cremer, D. (2011), "Leader mistreatment, employee hostility, and deviant behaviors: integrating self-uncertainty and thwarted needs perspectives on deviance", Organizational Behavior and Human Decision Processes, Vol. 117 No. 1, pp. 24-40.

Mesbahi, M. and Ismaeeli Tarzi, Z. (2017), "Investigating the relationship between organizational trust and deviant behaviors of employees at Payam Noor University of Kerman", Management Elite Conference.

Mohkamkar, I. and Hallaj, M.M. (2015), "What are social networks looking for?”, Journal of North Khorasan Police Knowledge, Vol. 2, pp. 87-108. 
Moqbal, M., Nevo, S. and Kock, N. (2013), “Organizational members' use of social networking sites and job performance", Information Technology and People, Vol. 26, pp. 240-264.

Morf, C.C. and Rhodewalt, M.F. (2001), "Unraveling the paradoxes of narcissism: a dynamic selfregulatory processing model”, Psychological Inquiry, Vol. 12 No. 4, pp. 177-196.

Mumford, M., Espejo, J., Hunter, S., Bedell-Avers, K., Eubanks, D. and Connelly, S. (2007), "The sources of leader violence: a comparison of ideological and nonideological leaders", The Leadership Quarterly, Vol. 18 No. 3, pp. 217-235.

Na'ami, Z. and Shekrshekan, H. (2004), "Investigating simple and multiple relationships between organizational justice and job satisfaction in employees of an industrial company", Journal of Educational Sciences and Psychology, Vol. 11 Nos 1/2, pp. 57-70.

Naami, A. and Shekrshekan, H. (2005), "Survey relationship organizational justice with ocb in employees of industrial organization in Ahvaz", Journal of Educational Sciences, Vol. 3 No. 13, pp. 79-92.

Neuman, J.H. and Baron, R.A. (2005), “Aggression in the workplace: a social psychological perspective”, Counterproductive Work Behavior: Investigations of Actors and Targets, American Psychological Association, Washington, DC, pp. 13-40.

Niaei, M., Peidaei, M.M. and Nasiripour, A.A. (2014), "The relation between staff cyber loafing and organizational commitment in organization of environmental protection", Kuwait Chapter of Arabian Journal of Business and Management Review, Vol. 3 No. 7, pp. 59-71.

Niehoff, B.P. and Moorman, R.H. (1993), "Justice as a mediator of the relationship between methods of monitoring and organizational citizenship behavior", Academy of Management Journal, Vol. 36 No. 3, pp. 527-556.

Organ, D.W. (1988), Organizational Citizenship Behavior: The Good Solider Syndrome, Lexington Books, Lexington, MA.

Pate, J. and Beaumont, P.H. (2009), "Bullying and harassment: a case of success", Employee Relations, Vol. 32 No. 2, pp. 171-183.

Pearson, C., Andersson, L. and Porath, C. (2005), "On the nature, consequences and remedies of workplace incivility: no time for "nice'? Think again", Academy of Management Perspectives, Vol. 19 No. 1, pp. 7-18.

Penney, L.M. (2002), "Narcissism and counterproductive work behavior: do bigger egos mean bigger problems?”, International Journal of Selection and Assessment, Vol. 10 Nos 1/2, pp. 126-134.

Reed, G. (2004), “Toxic leadership”, Military Review, pp. 67-71.

Roberts, B.W., Edmonds, G. and Grijalva, E. (2010), "It is developmental me, not generation me: developmental changes are more important than generational changes in narcissism - commentary on Trzesniewski and Donnellan", Perspectives on Psychological Science, Vol. 5 No. 1, pp. 97-102.

Sakhravi, R., Zahiri, A., Ahmadi, S. and Behnam, K.R. (2013), "The relationship between organizational justice and organizational self-esteem with regard to the mediating role of perceived organizational support among employees", Journal of Social Psychology, Vol. 8 No. 29, pp. 75-84.

Salmani, D. and Radmand, M. (2009), "Investigating the role of organizations and managers in the occurrence of deviant behaviors at work", Journal of Public Administration, Vol. 1 No. 3, pp. 51-68.

Schnake, M. (1991), "Organizational citizenship: a review, proposed model, and research agenda", Human Relations, Vol. 44 No. 7, pp. 735-759.

Shayan, A., Danaie, H. and Andami, M. (2017), "Investigating the effect of social media on job performance", The National Conference of Innovation in Systems and Information Technology Management with a Business Intelligence Approach, Vol. 1.

Shepherd, C. (2011), "Does social media have a place in workplace learning?", Strategic Direction, Vol. 27 No. 2, pp. 3-4.

Skarlicki, D. and Barclay, L. (2008), "When explanations for layoffs are not enough: in the workplace: the roles of distributive, procedural, and interactional justice", Journal of Applied Psychology, Vol. 82 No. 3, pp. 434-443. 
$\mathrm{XJM}$

$17,1 / 2$

Skarlicki, D.P. and Folger, R. (1997), "Retaliation in the workplace: the roles of distributive, procedural, and interactional justice)", Journal of Applied Psychology, Vol. 82 No. 3, pp. 343-443.

Stinson, F.S., Dawson, D.A., Goldstein, R.B., Chou, S.P., Huang, B., Smith, S.M. and Grant, B.F. (2008), "Prevalence, correlates, disability, and comorbidity of DSM-IV narcissistic personality disorder: results from the wave 2 national epidemiologic survey on alcohol and related conditions", The Journal of Clinical Psychiatry, Vol. 69 No. 7, pp. 1033-1045.

Taajobi, M., Abbas Zadeh, M., Hassani, M. and Ghalavandi, H., (2016), "The role of perceived organizational justice on job conflicts through the mediation of corporate identity", Studies of Educational Measurement and Evaluation Quarterly Journal, Vol. 12, pp. 153-177.

Tehrani, N. (2004), "Bullying: a source of chronic post traumatic stress?", British Journal of Guidance and Counseling, Vol. 32 No. 3, pp. 366-384.

Thomaes, S., Stegge, H., Bushman, B.J., Olthof, T. and Denissen, J. (2008), "Development and validation of the childhood narcissism scale", Journal of Personality Assessment, Vol. 90 No. 4, pp. 382-391.

Trzesniewski, K.H., Donnellan, M.B. and Robins, R.W. (2008), "Is 'generation me' really more narcissistic than previous generations?”, Journal of Personality, Vol. 76 No. 4, pp. 903-918.

Twenge, J.M., Konrath, S., Foster, J.D., Campbell, W.K. and Bushman, B.J. (2008), "Egos inflating over time: a cross-temporal meta-analysis of the narcissistic personality inventory", Journal of Personality, Vol. 76 No. 4, pp. 875-902.

Vazire, S., Naumann, L.P., Rentfrow, P.J. and Gosling, S.D. (2008), "Portrait of a narcissist: manifestations of narcissism in physical appearance", Journal of Research in Personality, Vol. 42 No. 6, pp. 1439-1447.

Vickers, M.H. (2006), "Writing what's relevant: workplace incivility in public administration - a wolf in sheep's clothing", Administrative Theory and Praxis, Vol. 28 No. 1, pp. 69-88.

Wink, P. and Gough, H.G. (1990), "New narcissism scales for the California psychological inventory and MMPI", Journal of Personality Assessment, Vol. 54 No. 3, pp. 446-462.

Wong, T., Hang, Y.N. and Wong, C.S. (2006), "Perceived organizational justice, trust, and OCB: a study of Chinese workers in joint ventures and state-owned enterprises", Journal of World Business, Vol. 41 No. 4, pp. $344-355$.

Yuan, Y., Raubal, M. and Liu, Y. (2010), "Correlating mobile phone usage and travel behavior - a case study of Harbin”, China. Computers, Environment and Urban Systems, Vol. 36 No. 2, pp. 118-130.

\begin{abstract}
About the authors
Arefeh Rahaei is a MA Student in Management Department at University of Shahid Ashrafi Esfahani, Isfahan, Iran. Her research interests include Business Management, Consumer Behavior, Marketing and Branding.

Reza Salehzadeh is an Assistant Professor in Management Department at University of Shahid Ashrafi Esfahani, Isfahan, Iran. His research interests include Leadership, Organizational behavior, Human resource management, Business management, Data mining and Kano model. He has published more than 60 articles at national and international levels in refereed journals and conferences. He is the author of two books and one book chapter entitled, Applications of Data Mining in Organizational Behavior (CRC, 2015). His work has been published in academic journals such as Journal of Management Development, International Journal of Educational Management, The Learning Organization, Asia Pacific Journal of Marketing and Logistics, Journal of Workplace Learning, International Journal of Culture, Tourism and Hospitality Research, Tourism Review, and Journal of International Consumer Marketing and TQM Journal. Reza Salehzadeh is the corresponding author and can be contacted at: r.salehzadeh@ashrafiac.ir
\end{abstract}

For instructions on how to order reprints of this article, please visit our website:

www.emeraldgrouppublishing.com/licensing/reprints.htm

Or contact us for further details: permissions@emeraldinsight.com 